\title{
Analysis of Enterprise Profitability Based on Dupont Analysis Method -Taking China Life Insurance (Group) Company as an Example
}

\author{
Ding $\mathrm{Li}^{1}$ \\ ${ }^{1}$ School of Jiangsu University of Science and Technology of Master of Accounting, Zhenjiang, Jiangsu 215300, China
}

\begin{abstract}
Obtaining profits is the main purpose of enterprise development, and profitability is the core indicator for measuring the development status and prospects of enterprises. DuPont analysis method is a comprehensive and effective financial analysis method to evaluate the profitability of enterprises. This article will focus on DuPont analysis method, supplemented by factor analysis method and comparative analysis method to comprehensively analyze the profitability of China Life Insurance Co., Ltd. Analyze the advantages and disadvantages of its profitability, then, give some relevant reasonable suggestions.
\end{abstract}

\section{INTRODUCTION}

With the improvement of China's consumption level and the rapid development of the social economy, the government attaches great importance and policy support to the development of the insurance industry, resulting in consumers' increasing attention to quality of life and health, and the awareness of insurance has gradually increased. The development of the Chinese insurance industry is also relatively stable. The business object of the insurance industry is mainly risk, providing risk protection for customers and achieving risk transfer. Of course, insurance companies are also for-profit organizations, and their core goal is to maximize value. However, the operating model and insurance products of insurance companies are special, so its profit model is slightly different from that of general industrial and commercial enterprises, and profitability is an important indicator to measure the pros and cons of a company's profit model.[1] Therefore, it is important to analyze the profitability of an enterprise significance.

Domestic and foreign scholars' research on the profitability of insurance companies involves many aspects, and the views presented are also diverse. For example: Pfeffer (1965) found that factors such as equity capital and operation and management capabilities have an important impact on the profitability of life insurance companies. [2] Malik (2011) found that asset size is positively correlated with profitability, and the loss ratio is negatively correlated with profitability.[3] At present, most of the research on the profitability of insurance companies analyzes the profitability of insurance companies based on the influencing factors. Since the DuPont analysis method was introduced in the 20th century, this method is mostly used in the research of manufacturing companies and applied to the insurance industry There is relatively little research on a specific company in China. This article will focus on DuPont analysis, supplemented by comparative analysis and factor analysis as the main methods of financial analysis, and combined with the overall status of the Chinese economy and the development prospects of the insurance industry, analyze the current profitability of China Life and propose corresponding Suggestions for improvement and improvement. China Life Insurance Co., Ltd. has a certain representativeness in China's insurance industry. Some of its problems and deficiencies are also common in other insurance companies. Therefore, by analyzing the profitability of China Life Insurance Co., Ltd., the guidance and reference significance for the development of other insurance companies in the insurance industry will be obtained.

\section{Selection of Profitability Evaluation Index of China Life Insurance Co., Ltd.}

\subsection{Index selection}

At present, with the improvement of social risk awareness and the improvement of social consumption level, residents are paying more and more attention to risk protection for themselves and their families, the concept of risk protection is gradually deepening, and the proportion of insurance assets in the allocation of household assets is further increased. This article starts with the comprehensive index of companies-return on net assets, mainly DuPont analysis, supplemented by comparative analysis and factor analysis, to analyze the financial and operating conditions of China Life Insurance Co., Ltd. The company's various financial indicators evaluate its profitability. 
The DuPont analysis method is mainly to use the correlation factors between several major financial ratios to comprehensively analyze the financial situation of the enterprise, and to decompose the return on net assets into products of multiple financial ratios layer by layer, which can more easily find the relevant factors that affect an indicator.[4] This will help to analyze the profitability of the company in depth and help to tap the weak links of the company. The main ratio relationship is shown in Figure
1. The net asset interest rate and equity multiplier mainly reflect the company's financial policies. The net sales rate and total asset turnover rate are mainly the embodiment of the company's business strategy. Comprehensive analysis of the advantages and disadvantages of China Life's financial policies and business strategies will help report users and stakeholders fully understand China Life's operating and financial status.[5]

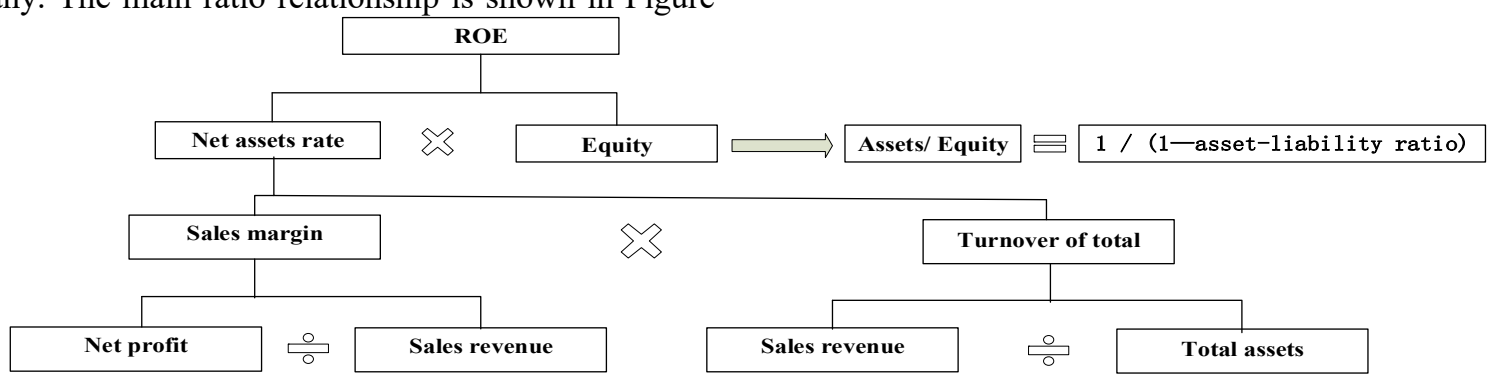

Figure1. DuPont analysis method main ratio relationship diagram

\subsection{Index analysis data source}

In order to analyze the profitability of China Life Insurance more comprehensively and accurately, it will analyze the financial data related to its and its comparative companies. The main data sources are the following three points:

a. Audited relevant financial statements submitted by China Life, Ping An and Pacific Insurance in the past five years, such as: balance sheet, cash flow statement, profit statement, cost calculation table, etc.

b. Three companies' annual reports and general ledger data for the past five years.

c. Announcement of other business subsystem data and major company matters.

\section{Indicator Anaysis}

\subsection{Roe}

The rate of return on net assets, also known as equity net interest rate, is the core ratio of the financial system. The level of return on net assets represents the level of return on investment.[6]

Return on net assets $=$ net asset interest rate $*$ equity multiplier $=$ sales net interest rate $*$ asset turnover rate $*$ equity multiplier

Table 1 China Life's main financial indicators

\begin{tabular}{|c|c|c|c|c|c|}
\hline Years & Roe & $\begin{array}{c}\text { Sales } \\
\text { margin }\end{array}$ & $\begin{array}{c}\text { Asset } \\
\text { turnov } \\
\text { er }\end{array}$ & $\begin{array}{c}\text { Equity } \\
\text { Multip } \\
\text { lier }\end{array}$ & $\begin{array}{c}\text { Net } \\
\text { assets } \\
\text { rate }\end{array}$ \\
\hline 2014 & $12.05 \%$ & $7.29 \%$ & 0.21 & 7.82 & $1.54 \%$ \\
\hline 2015 & $11.25 \%$ & $6.88 \%$ & 0.22 & 7.51 & $1.50 \%$ \\
\hline 2016 & $6.66 \%$ & $3.56 \%$ & 0.21 & 8.77 & $0.76 \%$ \\
\hline 2017 & $10.43 \%$ & $5.01 \%$ & 0.23 & 8.91 & $1.17 \%$ \\
\hline 2018 & $3.91 \%$ & $1.86 \%$ & 0.21 & 10.07 & $0.39 \%$ \\
\hline
\end{tabular}

It can be seen from Table 1 that the return on net assets of China Life Insurance Co., Ltd. fell from 12.05\% in 2014 to $6.66 \%$ in 2016 . This stage has a larger decline and rebounded in 2017, but in 2018 It has also dropped significantly. In general, it shows a very unstable fluctuation trend, which shows that the income level of the shareholders' equity of China Life Insurance Co., Ltd. is in an unstable state. From the annual report, it can be seen that the total asset turnover rate has not changed much, and the equity multiplier has not changed in line with the return on net assets. The unstable state is mainly related to the sales net interest rate and equity multiplier. The following is a factor analysis of China Life 's return on net assets in the past two years, using the relevant indicator data in 2018 to replace the relevant indicator data in 2017, and analyzing the impact of changes in various indicators on the return on net assets.

Base: 2017 return on net assets $=0.0501 * 0.23 * 8.91$ $=0.1043$; replacement sales net interest rate $=0.0186 *$ $0.23 * 8.91=0.0381$; replacement total asset turnover rate $=0.0186 * 0.21 * 8.91=0.0348$; replacement equity multiplier $=0.0186 * 0.21 * 10.07=0.0393$

The impact degree of each indicator change is as follows: The impact of changes in sales net interest rate $=$ $0.0381-0.1043=-6.62 \%$; the impact of changes in total asset turnover rate $=0.0348-0.0381=-0.33 \%$; the impact of changes in equity multiplier $=0.0393-0.0348=0.45 \%$

By analyzing the financial data of China Life in 2017 and 2018 by factor analysis, it can be seen that the biggest impact on its return on net assets is the reduction in sales net interest rate, which reduces the return on net assets by $6.62 \%$; followed by the reduction in total asset turnover, Decreased the return on net assets by $0.33 \%$; while the equity multiplier has increased compared with 2017, resulting in an increase in return on net assets by $0.45 \%$. The effect of the above factors has reduced the return on net assets by $6.5 \%$. The main reason is that the overall economic downturn in 2018 has caused China Life's asset impairment loss and fair value change loss to be greatly strengthened, plus Cost and cost control is poor, resulting 
in a substantial reduction in operating profit and net profit, which affects the rate of return on net assets.

In order to further analyze China Life's return on net assets, the following compares China Life's return on net assets with relevant data from China Ping An and China Pacific Insurance to further explore China Life's financial status.

\section{Figure2 Comparison of return on net assets}

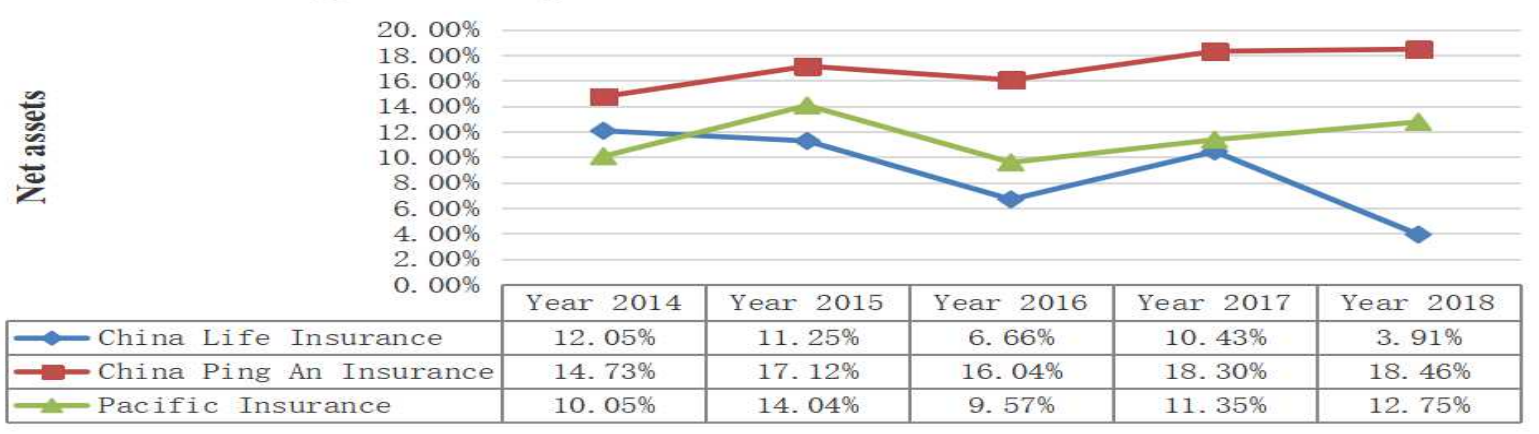

As shown in Figure 2, the return on net assets of the three companies showed a downward trend from 2015 to 2016, mainly due to the large scale of competition in the insurance market in 2016, and the return on investment of insurance companies generally decreased, resulting in a decline in overall profit in the insurance industry. Therefore, the return on net assets of the three insurance companies decreased from 2015 to 2016 . As can be seen from Figure 2, Ping An's return on net assets is the highest of the three, and the range of change is the smallest of the three. It is quite competitive in the insurance market. The return on net assets of China Life Insurance and Pacific Insurance both showed up and down trends. Although the absolute value of China Life Insurance is the smallest of the three, it is still greater than the bank interest rate. This shows that the overall profitability of China Life
Insurance Co., Ltd. is There is still a certain degree of competitiveness in the industry, but the return on net assets is unstable, which increases the business risks of enterprises. To sustainably and steadily develop in the insurance market, it is necessary to reduce the fluctuation of the return on net assets and further enhance competitiveness.

\subsection{Sales margin}

Net profit margin represents the level of income from sales revenue and reflects the ability of an enterprise to obtain sales revenue over a certain period of time.

Net profit margin $=$ net profit $/$ sales revenue

\begin{tabular}{|c|c|c|c|c|c|}
\hline \multicolumn{7}{|c|}{ Table 2 China Life Insurance Net Profit Related Data } \\
\hline (ten thousand yuan) & Year 2014 & Year 2014 & Year 2014 & Year 2014 & Year 2014 \\
\hline Net profit & 3251400 & 3518700 & 1955400 & 3275200 & 1193600 \\
\hline Sales revenue & 44577300 & 51136700 & 54977100 & 65319500 & 64310100 \\
\hline Operating expenses & 40552000 & 46535400 & 52571500 & 61131300 & 62881400 \\
\hline Other profits & 14900 & -8200 & -24500 & -21100 & -36600 \\
\hline Income tax expense & 788800 & 1074400 & 425700 & 891900 & 198500 \\
\hline
\end{tabular}

As can be seen from Table 2, China Life Insurance Co., Ltd.'s sales net interest rate and net asset return rate change trends are generally consistent. It can be seen from Table 2 that during the period of 2015-2018, China Life Insurance Co., Ltd.'s net profit and sales net interest rate changed basically the same, while from 2014 to 2015, the net profit rate of sales showed a downward trend, net profit The upward trend is mainly due to the fact that the growth rate of sales revenue during this period far exceeded the growth rate of net profit, which led to a decline in the net sales rate in 2014-2015. During 20152016, the net profit of sales showed a significant downward trend. After consulting the financial information of China Life Insurance Co., Ltd., it can be seen that from 2015 to 2016, China Life Insurance Co., Ltd.'s handling fees, commission expenses, and compensation expenses were net. The amount increased significantly compared to 2015. The reason for the increase is mainly due to the significant increase in the number of employees in the insurance industry in China by 2016 , the per capita marketing costs have increased significantly, and the high growth rate of marketers has placed a greater burden on the company. And 2017-2018 sales of net profit fell significantly, by looking at financial data, it was found that while sales revenue in 2018 was significantly reduced, sales expenses were increasing, resulting in a decrease in net profit and a sharp decline in net sales interest rate. 


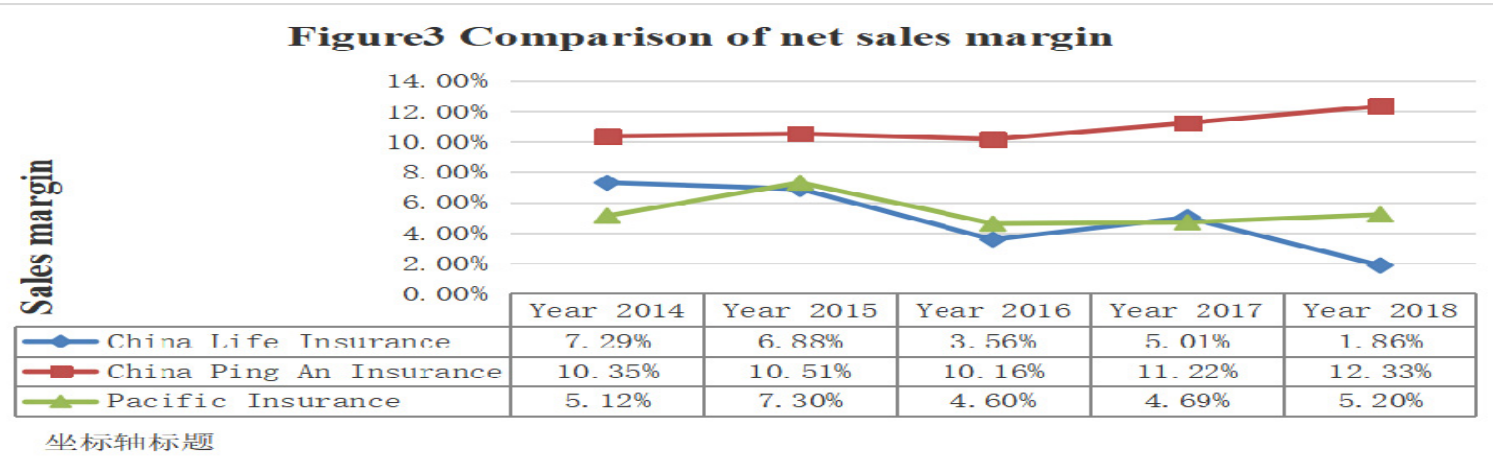

As shown in Figure 3, comparison of trends in net sales margin is consistent with the corresponding net asset yield trends shown in Figure 3. It can be seen from 3 that Ping An 's sales margins from 2014 to 2018 have basically maintained a stable and rising trend, while the sales margins of China Life and Pacific Insurance have remained unstable and fluctuating, and the sales margins of Ping An are obvious Higher than China Life and Pacific Insurance, which shows that China Life and Pacific Insurance's profitability is lower than China Ping An.

\subsection{Asset turnover}

Asset turnover rate is an indicator to measure the asset management capability of an enterprise, and it reflects the turnover rate of total assets. The faster the turnover rate, the stronger the sales ability of the enterprise.

Total asset turnover $=$ sales revenue $/$ average total assets

As can be seen from Table 1, the fluctuation of asset turnover rate of China Life Insurance Co., Ltd. is generally relatively stable, moving up and down between $0.21-0.23$. This is because of the change in operating income and the average total assets in each year The level of change is not much different, and the asset turnover rate is relatively low compared to other industries. The significantly higher total assets are the main reason for its lower asset turnover rate. The asset turnover rate of China Life Insurance Co., Ltd. is relatively stable. It can be seen that the asset management capability of China Life Insurance is still quite good.

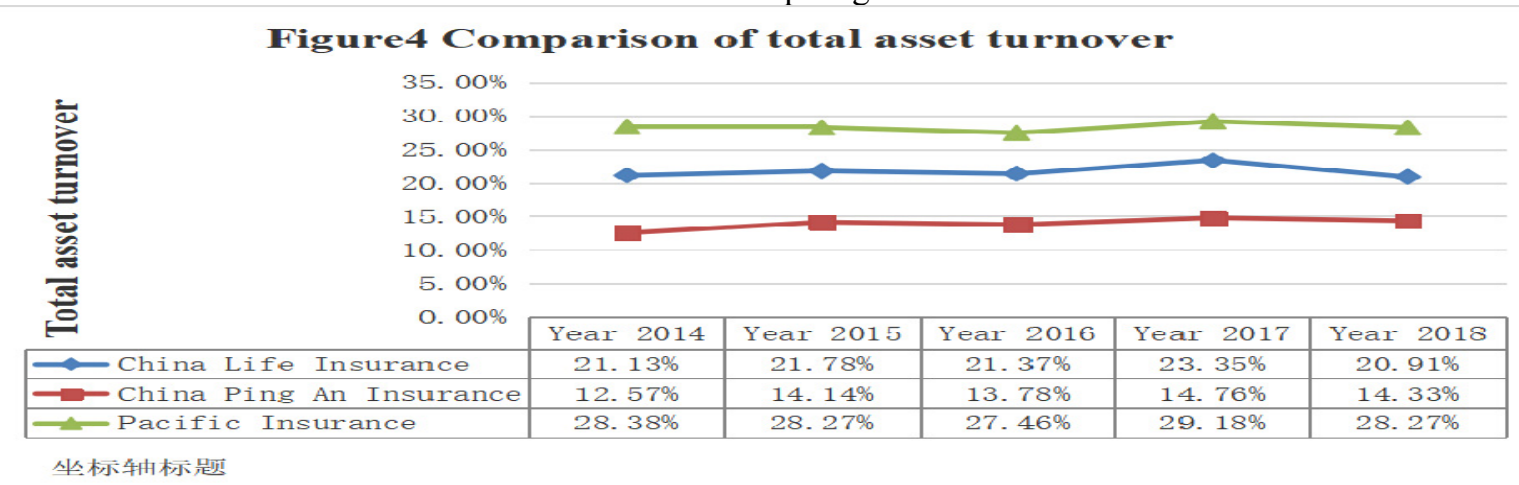

As shown in Figure 4, the asset turnover rates of the three insurance companies are relatively stable. The asset turnover rates of China Life and Pacific Insurance are higher than those of China. Ping An is high, which shows that the asset management capabilities of the three leading companies in China's insurance industry are still quite good. By looking at the operating income and total asset data that affect the asset turnover rate in the financial information of various companies, we can see that China Ping An has the highest total assets, followed by China Life, and Pacific Insurance has the lowest total assets. It can be inferred that Pacific Insurance has the fastest turnover of total assets and the strongest sales capacity; China Ping An has the lowest turnover of total assets and relatively weak sales capacity; China Life Insurance is somewhere between the two and its sales capacity is not strong Not weak, there is room for strengthening. Total corporate assets have a greater impact on total asset turnover. Ping An's significantly higher total assets are the main reason for its lowest asset turnover.

\subsection{Equity Multiplier}

The equity multiplier is an important indicator to measure the debt level of an enterprise. The larger the equity multiplier, the higher the debt level of the enterprise.

Equity multiplier $=$ total assets $/$ shareholders' equity $=$ $1 /$ (1-total liabilities / total assets $) * 100 \%$

As can be seen from Table 1, the equity multiplier of China Life Insurance Co., Ltd. decreased from 7.82 in 2014 to 7.51 in 2015, indicating that China Life Insurance Co., Ltd. reduced its debt level during this year. From 2016 to 2018, the equity multiplier of China Life Insurance Co., Ltd. rose from 7.51 in 2015 to 10.07 in 2018, indicating that during this period, China Life Insurance Co., Ltd. increased its debt level, although this can increase the company 's Capital utilization and reduce the company's opportunity cost, but the high equity multiplier also means that the greater the financial risk 
facing the company. Therefore, the company should also pay careful attention to the company's equity multiplier index and control the index within a reasonable range.

Figu res Comparison of equity multipliers

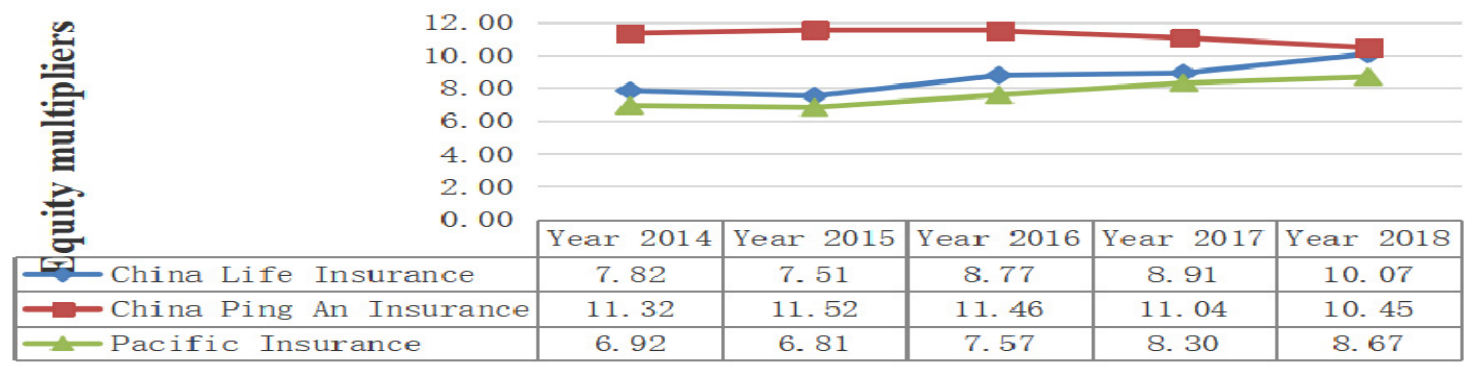

坐标轴标题

As can be seen from Figure 5, to analyze the equity multiplier, it is necessary to analyze the total assets and total equity that affect the equity multiplier. The total assets of the three companies have been analyzed above, that is, China Ping An has the highest total assets, followed by China Life Insurance, Pacific Insurance has the lowest total assets, and the total assets of the three companies are increasing year by year. China Life and Pacific Insurance 's equity multiplier in the past five years is in line with the change in total assets, while Ping An 's equity multiplier is in a relatively stable trend. Life Insurance, the lowest is Pacific Insurance, which shows that high total assets is one of the reasons for the high equity multiplier.

\section{CONCLUSION}

In summary, this paper analyzes the profitability of China Life Insurance Co., Ltd. through DuPont analysis, factor analysis, and comparative analysis. It can be seen that although China Life 's financial situation in the past five years is relatively unstable, the company 's The overall financial situation is still within normal limits. China Life Insurance Co., Ltd.'s business distribution, marketing channels, and cost control need to be improved. The main problems are as follows: First, the profitability. Due to the fierce competition in the insurance industry and the saturation of the market in recent years, the overall economic downturn, coupled with insufficient cost control, has made the company's sales profit margin and net asset profit margin unstable. The second is the equity multiplier. The equity multiplier of the company as a whole shows an upward trend, and the equity multiplier is high, indicating that the company has excessively increased the level of financial leverage through debt and other means and increased the financial risk of the company.

Therefore, if China Life Insurance Co., Ltd. wants to develop better, it should promote more efficient sales process of insurance products, strengthen personnel management, and improve cost control. First, the company should increase scientific and technological innovation, save labor costs, pay attention to the cultivation and encouragement of marketing personnel, use Internet thinking to streamline the company level, retain the necessary departments, and improve management efficiency. Second, reduce the channel cost through the network direct sales channel instead of the traditional insurance sales personnel exclusive service channel, thereby reducing the cost of insurance product sales, and the prerequisite for this measure is to enhance brand reputation, expand publicity, and enhance customer satisfaction. Third, the company should pay careful attention to the company's equity multiplier index, and control the index within a reasonable range, so as not to overly high asset-liability ratio affect the company's earnings and development.

\section{References}

1. C. Wenhui, (2008) Research on Operation Law of China Life Insurance Industry: Expenses, breakeven, capital requirements. North Beijing: China Financial Publishing House., 2(2): 32-39.

2. I. Pfeffer, (1965) Measuring the Profit Potential of a New Life Insurance Company. The Journal of Risk and Insurance., 32(3): 413-422.

3. H. Malik, (2011) determinants of insurance companies profitability: Ananlysis of insurance sector of pakistan. Academic Research International., 1(3): 315-319.

4. G. Chengming, (2005) Construction of profitability analysis system for life insurance companies. Financial Times., 10.

5. L.Weixiang, (2006) Five Factors Analysis of DuPont Financial System. Accounting Research., (5): 56-57.

6. Z. Yahui, (2005) Listed company profitability analysis. China's scientific and technological information., (3): 49. 